\title{
Magnetic resonance imaging and pathological features of a mixed glioma in a dog: case report
}

\author{
[Aspectos patológicos e das imagens de ressonância magnética de um glioma misto \\ em um cão: relato de caso] \\ T.M. Granato ${ }^{1}$, L.P. Mesquita ${ }^{1}$, R.C. Costa ${ }^{1}$, J.P. Andrade Neto ${ }^{2}$, P.C. Maiorka ${ }^{1 *}$ \\ ${ }^{1}$ Universidade de São Paulo - São Paulo, SP \\ ${ }^{2}$ Consultórios Veterinários Alto da Lapa - São Paulo, SP
}

\begin{abstract}
The aim of this report was to describe the magnetic resonance imaging (MRI) and pathological features of a canine mixed glioma. A 12-year-old boxer male dog was presented for necropsy along with data from an MRI evaluation conducted ante-mortem. The images were examined and showed a poorly demarcated prosencephalic lesion, hyperintense on $\mathrm{T} 2 \mathrm{~W}$ images, hypointense on $\mathrm{T} 1 \mathrm{~W}$ images and heterogeneously hyperintense on T2W FLAIR images. There was mild nonuniform contrast enhancement, apparent midline shift, moderate perilesional edema and marked distortion of the adjacent lateral ventricle. The brain was evaluated macroscopically, microscopically and immunohistochemically. Grossly, there was a poorly demarcated soft mass, with areas of hemorrhage, within the left parietal and temporal lobes. Histologically, there was a densely cellular mass composed of two geographically distinct populations of neoplastic cells. The first population was composed of small and round cells organized in a honeycomb pattern. The second population constituted of intermingled streams and bundles of neoplastic cells that were strongly immunolabeled for glial fibrillary acidic protein (GFAP). The diagnosis of a mixed glioma was based on MRI findings, and mainly on histological and immunohistochemical findings.
\end{abstract}

Keywords: mixed glioma, dogm, MRI, pathology

\section{RESUMO}

O objetivo deste relato foi descrever as características patológicas e das imagens de ressonância magnética de um glioma misto canino. Um cão de 12 anos de idade da raça Boxer foi submetido à necropsia. As imagens obtidas ante mortem por ressonância magnética foram analisadas, e nelas se observou uma lesão prosencefálica com contornos pouco definidos, sinal hiperintenso nas imagens ponderadas em T2, hipointenso nas imagens ponderadas em T1, e heterogeneamente hiperintenso em T2FLAIR. Havia discreto realce desuniforme ao contraste, evidente desvio da linha média, edema perilesional moderado e marcada distorção do ventrículo lateral adjacente. $O$ encéfalo foi avaliado macroscopicamente, microscopicamente e imuno-histoquimicamente. Macroscopicamente, havia uma massa pobremente demarcada, com áreas de hemorragia, nos lobos parietal e temporal esquerdos. Histologicamente, havia uma massa densamente celular, composta por duas populações de células neoplásicas distintas separadas geograficamente. A primeira população era composta por células pequenas e redondas, organizadas com aspecto de favo de mel. A segunda população era constituída por feixes entrelaçados de células neoplásicas fortemente imunomarcadas para a proteína fibrilar ácida glial (GFAP). O diagnóstico de glioma misto foi obtido com base nos achados imaginológicos e, principalmente, em suas características histológicas e imuno-histoquímicas.

Palavras-chave: glioma misto, cão, ressonância magnética, patologia

Recebido em 20 de dezembro de 2017

*Autor para correspondência (corresponding author)

Aceito em 22 de maio de 2018

E-mail: maiorka@usp.br 


\section{INTRODUCTION}

Gliomas are a type of neoplasm that arises from glial cells in the brain or spinal cord and includes oligodendrogliomas, astrocytomas and mixed gliomas (Bentley et al., 2016). Gliomas are the second most frequent intracranial neoplasms in dogs and, as in humans, they occur in middleaged and senile individuals, especially brachycephalic dogs, in particular the boxer breed (Bentley et al., 2016; Young et al. 2011).

Vandevelde et al. (2012) state that mixed gliomas are a subtype of glioma composed by neoplastic astrocytes and oligodendrocytes, either intermingled or separated in different clusters, and represent only $5 \%$ of all canine gliomas.

Magnetic resonance imaging (MRI) is a noninvasive diagnostic method that has been used for presumptive or prioritized differential diagnosis of intracranial lesions in dogs. Although several studies have reported MRI findings in dogs with astrocytomas and oligodendrogliomas (Bentley et al., 2016; Bentley, 2015; Bentley et al., 2013; Wisner et al., 2011; Young et al., 2011), there are, to the authors' knowledge, only two descriptions of imaging findings of histologically confirmed canine mixed gliomas in the literature: one comprised multi-focal lesions in a Cavalier King Charles Spaniel puppy - an atypical presentation (Walmsley et al., 2009), and the other was a focal lesion superficially located, which gave it an appearance of an extra-axial lesion (Ródenas et al., 2011).

The aim of this report was to describe a canine mixed glioma, regarding its imaginological, histological and immunohistochemical findings.

\section{CASUISTRY}

A 12-year-old boxer male dog was presented for necropsy to the Department of Pathology of the School of Veterinary Medicine and Animal Science, at the University of São Paulo, with only a brief history of altered mental status, head pressing, compulsive walking and circling to the left side, right side motor and visual deficits, that suggested a lesion on the left cerebral hemisphere (de Lahunta and Glass, 2009). Data from the MRI evaluation conducted ante-mortem on a low-field equipment (Vet-MR Grande,
Esaote) were examined and a round lesion was observed on the left cerebral hemisphere, with ill-defined margins, apparent midline shift, moderate peritumoral edema, and marked distortion of the left lateral ventricle (Figure 1A). The lesion was approximately 33 x 25 x 30mm (height $\mathrm{x}$ width $\mathrm{x}$ length), showed hyperintense signal with a hypointense linear central area on T2 weighted (T2W) images, mild hypointensity with a slightly hyperintense amorphous central area on $\mathrm{T} 1$ weighted (T1W) images, heterogeneously hyperintense signal on $\mathrm{T} 2$ weighted fluid attenuated inversion recovery (T2W FLAIR) images, and mild non-uniform contrast enhancement after gadolinium injection (Figure 1B). The entire central nervous system (CNS) was fixed in $10 \%$ buffered formalin and routinely processed for histology. CNS sections were stained with hematoxylin and eosin and were also submitted for immunohistochemistry for detection of glial fibrillary acidic protein (GFAP) as described by Mesquita et al. (2016).

Grossly, there was a whitish, poorly demarcated, soft mass, with areas of hemorrhage, within the left parietal and temporal lobes, adjacent to the lateral ventricles (Figure 1C). The mass displaced the left lateral ventricle down and the right ventricle to the side. Histologically, within the white matter and extending to the gray matter there was an infiltrative, non-encapsulated, poorly demarcated, densely cellular mass composed of two geographically distinct populations of neoplastic cells. The first population comprised approximately $60 \%$ of the entire neoplastic formation and it was composed of a sheet of neoplastic cells in a delicate preexisting stroma. These cells were small and round, with indistinct cell borders with a moderate amount of a clear and vacuolized cytoplasm, giving an aspect of honeycomb to the organization of these cells (Figure 1D). The nuclei were round to oval, hyperchromatic with clumped chromatin and indistinct nucleoli. There was a moderate anisocytosis and anisokaryosis, with 4 mitotic figures in 10 400x higher power fields (HPF), and multifocal areas of hemorrhage. The second population of cells comprised approximately $40 \%$ of total neoplastic cells. This second population was adjacent to the first, and it was composed of intermingled streams and bundles of neoplastic cells within a pre-existing stroma with large number of newly formed vessels (glomeruloid vessels). The 
neoplastic fusiform cells had indistinct cell borders, with an abundant, eosinophilic, sometimes fibrillary, cytoplasm. The nuclei were elongated to fusiform, euchromatic, centrally located, with a finely stippled chromatin and 1 to 2 basophilic nucleoli. There was a marked anisocytosis and anisokaryosis with occasional multinucleated and bizarre cells. This population of neoplastic cells had multifocal areas of necrosis lined by neoplastic cells organized in palisade, as well as foci of mineralization and lymphocytic infiltrate. Three mitotic figures were visualized within 10HPF. In addition, the neoplasm compressed the adjacent neuropil, in association with a diffuse and marked astrogliosis with a large number of gemistocytes.
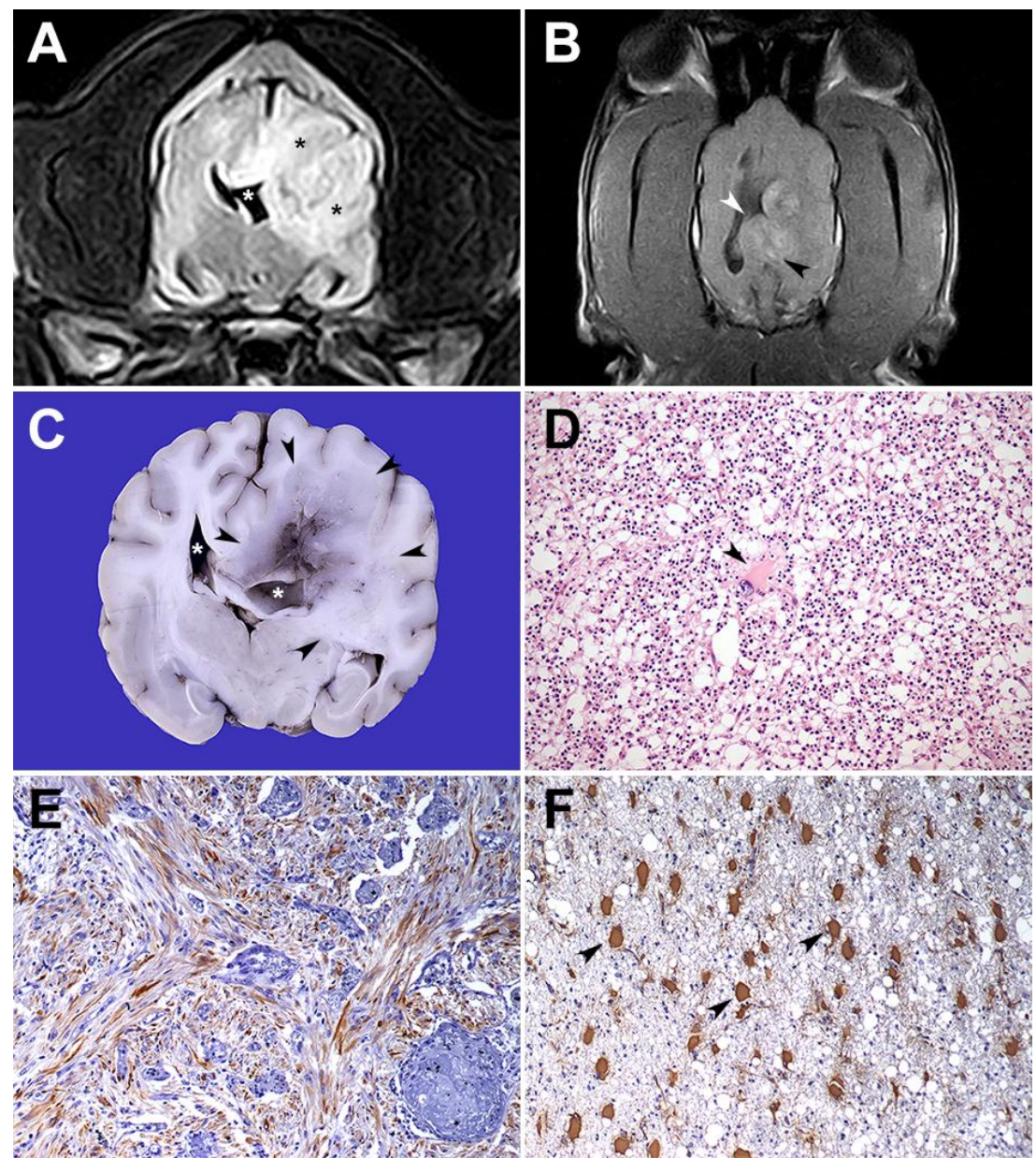

Figure 1. A 12-year-old boxer male dog with neurological signs diagnosed with a mixed glial tumor. A. In this T2W FLAIR transversal section at the level of the thalamus, the poorly demarcated heterogeneously hyperintense lesion (black asterisks) is seen on the left cerebral hemisphere causing distortion of the left lateral ventricle (white asterisk) and a midline shift to the right. B In this T1W dorsal section obtained after gadolinium injection, the lesion shows mild nonuniform contrast enhancement (black arrowhead) and protrudes towards the right hemisphere through the lateral ventricles (white arrowhead). The left ventricle cannot be seen in this section, because it was compressed and moved down as seen in C. C. The mass was whitish, poorly demarcated (arrowheads), with central areas of hemorrhage and with displacement of lateral ventricles (asterisks). D. The oligodendroglial population is composed by round and small cells with hyperchromatic nuclei organized in a honeycomb pattern. In the center of the figure (arrowhead), there is a reactive astrocyte (gemistocyte), hematoxylin and eosin (HE) stain, 100x. E. The astroglial population was composed by spindle shaped neoplastic cells which exhibited intracytoplasmic staining for GFAP (brown staining), immunohistochemistry (IHC) for GFAP, 100x. F. In the peritumoral area, there was a marked astrogliosis with a large number of reactive astrocytes (gemistocytes; arrowheads) immunolabeled for GFAP, IHC for GFAP, 100x. 
A moderate number of neoplastic cells from the second population had a strong immunolabeling for GFAP (Figure 1E). Also, anti-GFAP staining revealed a marked astrogliosis with formation of gemistocytes around the neoplasm (Figure 1F). Reactive astrocytes were detected in a moderate number intermingled with the first population of neoplastic cells.

Based on histological findings, the first population of neoplastic cells was consistent with a well-differentiated oligodendroglioma. Along with immunohistochemistry, the second population was diagnosed as a high-grade astrocytoma (WHO grade IV) (Koestner et al., 1999). The oligodendroglioma counterpart comprised $60 \%$ of the entire tumor, whereas the astrocytic formation comprised $40 \%$ of the mass. Therefore, the tumor was diagnosed as a mixed glioma, since there was at least $25 \%$ to $30 \%$ of either cell type (Koestner et al., 1999; Vandevelde et al., 2012).

\section{DISCUSSION}

The diagnosis of a mixed glioma in the dog from the present report was based on MRI findings, and mainly on histological and immunohistochemical findings. The neoplasm was composed by an oligodendroglial population, which was characteristically organized in a honeycomb pattern and by an astrocytic component immunolabeled for GFAP. As stated by Vandevelde et al. (2012), the diagnosis of a mixed glioma seems unambiguous if the neoplasm population is composed of at least $30 \%$ of either cell type.

The periventricular location of the neoplasm described here is a commonly affected area by oligodendrogliomas (Vandevelde et al., 2012; Young et al. 2011) and astrocytomas, whose origin may be in the neural stem cells located in the periventricular white matter (Young et al., 2011). The globoid shape of the mass presented here resembles the astrocytomas and oligodendrogliomas described by Wisner et al. (2011), and the severe mass effect was found in more than $90 \%$ of the oligodendrogliomas and astrocytomas evaluated by Bentley (2015). A lateral ventricle distortion is seen in both astrocytomas and oligodendrogliomas, but more frequently in the latter (Bentley et al., 2013). Perilesional edema was found in most gliomas and, to an inferior degree, in meningiomas and nasal tumors studied by Ródenas et al. (2011). Even though canine gliomas usually have welldefined margins (Young et al., 2011), on MRI the tumor presented here had ill-defined margins consistent with the macroscopic and histopathologic findings. The presence of nonuniform contrast enhancement agrees with the findings in the mixed glioma presented by Walmsley et al. (2009) and correlates with the histologically found newly formed vessels in the astrocytic portion of this neoplasm, probably because grade IV astrocytomas' neovascularization is flawed (Dubois et al., 2014), therefore allowing the leakage of gadolinium injected intravenously. Although higher grade gliomas tend to show higher degree of contrast enhancement, this trait cannot be used as a valid criterion of biological grade (Wisner and Zwingenberger, 2015). The lesion described here had a central area with hypointense signal on T2W images and mildly hyperintense signal on T1W images, which coincides in position with the hemorrhagic area observed grossly. These signal intensities correspond to the presence of intracellular meta-hemoglobin seen in early sub-acute hemorrhages (Hecht and Adams, 2010), and were also seen in an oligodendroglioma reported by Ródenas et al. (2011). As non-neoplastic differentials for solitary intraparenchymal enhancing lesions, Bentley (2015) suggests primary inflammatory diseases, as granulomatous meningoencephalomyelitis, and fungal infections, that often cause extensive perilesional edema. Nevertheless, the signal hypointensity on $\mathrm{T} 1 \mathrm{~W}$ images and hyperintensity on $\mathrm{T} 2 \mathrm{~W}$ images support the findings in the mixed glioma reported by Walmsley et al. (2009) and other tumors reported by Bentley (2015), who stated that signal heterogeneities, particularly on $\mathrm{T} 2 \mathrm{~W}$ FLAIR images, are typically predictive of neoplasms.

Although in humans MRI features are highly specific in discerning astrocytomas from oligodendrogliomas, Young et al. (2011) were unable to indicate specific imaging properties that could distinguish these neoplasms in dogs. The mixed glioma described here coincided with the mixed glioma reported by Walmsley et al. (2009) regarding signal intensities, presence of mass effect, perilesional edema and contrast enhancement, but the number of lesions and the 
age of the patients were very different. The mixed glioma presented by Ródenas et al. (2011) also showed mixed signal intensity on T2W images but was isointense on T1W images. There was no further information on mass effect, perilesional edema and contrast enhancement in the latter mixed glioma report. Therefore, our evaluation of a single canine mixed glioma combined with the other two reports present in the literature was insufficient in the attempt to find distinct features of this tumor type. Studies done with a larger number of patients might increase the specificity of MRI evaluations in differentiating particular glioma types in veterinary patients.

MRI findings, such as lesion location and demarcation, presence of perilesional edema, contrast enhancement and midline shift, strongly correlated to its histological features, and along with patient's age and breed, T1W hypointensity, T2W hyperintensity, T2W FLAIR heterogeneities, as seen in the present case, were highly suggestive of a neoplasm of glial origin, which was confirmed histologically and immunohistochemically. Therefore, MRI is an important tool that can provide, noninvasively, critical data for a presumptive diagnosis of intracranial gliomas in dogs.

\section{ACKNOWLEDGMENTS}

The authors thank Professor Aloísio Souza Felipe da Silva for lending the equipment to photograph the slides, and CAPES for the financial support.

\section{REFERENCES}

BENTLEY, R.T. Magnetic resonance imaging diagnosis of brain tumors in dogs. Vet. J., v.205, p.204-216, 2015.

BENTLEY, R.T.; AHMED, A.U.; YANKE, A.B. et al. Dogs are man's best friend: in sickness and in health. Neuro-Oncol., v.19, p.312-322, 2016.

BENTLEY, R.T.; OBER, C.P.; ANDERSON, K.L. et al. Canine intracranial gliomas: relationship between magnetic resonance imaging criteria and tumor type and grade. Vet. J., v.198, p.462-471, 2013.
DE LAHUNTA, A.; GLASS, E. Veterinary neuroanatomy and clinical neurology. St. Louis: Saunders, 2009. 600p.

DUBOIS, L.G.; CAMPANATI, L.; RIGHY, C. et al. Gliomas and the vascular fragility of the blood brain barrier. Front. Cell. Neurosci., v.8, p.418, 2014.

HECHT, S.; ADAMS, W.H. MRI of brain disease in veterinary patients part 2: acquired brain disorders. Vet. Clin. Small Anim. Pract., v.40, p.39-62, 2010.

KOESTNER, A.; BILZER, T.; FATZER, R. et al. Histological classification of tumors of nervous system of domestic animals. 2.ed, Washington: Armed Forces Institute of Pathology, 1999. 71p.

MESQUITA, L.P.; HORA, A.S.; SIQUEIRA, A. et al. Glial response in the central nervous system of cats with feline infectious peritonitis. J. Feline Med. Surg., v.18, p.1023-1030, 2016.

RÓDENAS, S.; PUMAROLA, M.; GAITERO, L. et al. Magnetic resonance imaging findings in 40 dogs with histologically confirmed intracranial tumours. Vet. J., v.187, p.85-91, 2011.

VANDEVELDE, M.; HIGGINS, R.J.; OEVERMANN, A. Neoplasia. In: __. Veterinary neuropathology: essentials of theory and practice. Ames: Wiley-Blackwell, 2012. cap.7, p.129-156.

WALMSLEY, G.L.; CHANDLER, E.S.; DAVIES, C.R. et al. Multi-focal cerebral oligoastrocytoma in a puppy. J. Small Anim. Pract., v.50, p.435-439, 2009.

WISNER, E.R.; DICKINSON, P.J.; HIGGINS, R.J. Magnetic resonance imaging features of canine intracranial neoplasia. Vet. Radiol. Ultrasound, v.52, p.S52-S61, 2011.

WISNER, E.R.; ZWINGENBERGER, A.L. Brain. In: _. Atlas of small animal CT and MRI. Ames: Wiley-Blackwell, 2015. cap.2, p.153-278.

YOUNG, B.D.; LEVINE, J.M.; PORTER, B.F. et al. Magnetic resonance imaging of intracranial astrocytomas and oligodendrogliomas in dogs. Vet. Radiol. Ultrasound, v.52, p.132-141, 2011. 